\title{
Feeding habits of the crab-eating fox, Cerdocyon thous (Carnivora: Canidae), in a mosaic area with native and exotic vegetation in Southern Brazil
}

\author{
Vlamir J. Rocha 1; Lucas M. Aguiar 2; José E. Silva-Pereira ${ }^{2}$; Rodrigo F. Moro-Rios ${ }^{2}$ \& Fernando C. Passos ${ }^{2}$ \\ ${ }^{1}$ Bioecologia e Manejo Integrado de Pragas e Doenças Florestais, Pesquisa Florestal, Klabin S.A. Avenida Araucária, \\ 84279-000 Lagoa, Paraná, Brasil. E-mail: vlamir@klabin.com.br \\ 2 Programa de Pós-graduação em Zoologia, Laboratório de Biodiversidade, Conservação e Ecologia de Animais Silvestres, \\ Departamento de Zoologia, Universidade Federal do Paraná. Caixa Postal 19020, 81531-980 Curitiba, Paraná, Brasil.
}

\begin{abstract}
Cerdocyon thous (Linnaeus, 1766) is the most widespread neotropical canid, most commonly inhabiting forested areas. This animal is a generalist omnivore that is able to use environments disturbed by human activities. The aim of this study was to describe its diet through the stomach content analysis of 30 samples obtained from specimens that were run over in a mosaic composed by Araucaria Pine Forest, Semidecidual Seasonal Forest, natural grasslands, and exotic vegetation. The items were quantified by frequency of occurrence (F.O.) and percentage of occurrence (P.O.). A total of 64 food items were found among 171 occurrences. According to F.O. method, plant items corresponded to $93.3 \%$ of the occurrences, followed by animal items $(86.7 \%)$ and human rejects (16.6\%). Among plants, fruits accounted for $92.9 \%$ of the occurrences, followed by leaves $(53.6 \%)$ and flowers (10.7\%). Syagrus romanzoffianum (Cham.) Glassman, 1968 and the exotic Hovenia dulcis Thunberg were the most consumed fruits (30\% each), and the most consumed leaves were Poaceae. Among preyed animals, the F.O. was $73.3 \%$ for invertebrates (mostly Orthoptera and Coleoptera, 36.7\% each) and $63.3 \%$ for vertebrates (mostly mammals, 33.3\%). Regarding the P.O. method, there was an overestimation of invertebrates $(98.1 \%)$ due to the presence of ants and termites in the stomach of a single individual. In general, $C$. thous presented its usual diet. Its generalistic feeding habits can positively influence its survival in altered environments. This study also compares different methods for dietary analysis and discusses some opportunistic behaviors of $C$. thous, such as the consumption of exotic species and the use of silviculture areas as hunting sites.

KEY WORDS. Carnivorous; diet; exotic species; frugivory; neotropical canid; silviculture.
\end{abstract}

RESUMO. Hábito alimentar do cachorro-do-mato, Cerdocyon thous (Carnivora: Canidae), em área de mosaico de vegetação nativa e exótica no Sul do Brasil. Cerdocyon thous (Linnaeus, 1766) é o canídeo neotropical mais amplamente distribuído e habita principalmente ambientes florestados. Este animal possui hábito alimentar onívoro generalista e demonstra capacidade de utilizar ambientes perturbados pela ação do homem. $O$ objetivo deste trabalho foi descrever sua dieta através da análise de 30 conteúdos estomacais de espécimes atropelados, provenientes de um mosaico constituído por Floresta Ombrófila Mista, Floresta Estacional Semidecidual, Campos Naturais e vegetação exótica. Os itens foram quantificados em frequêência de ocorrência (F.O.) e porcentagem de ocorrência (P.O.). No total foram identificados 64 itens, distribuídos em 171 ocorrências. De acordo com o método F.O., itens vegetais ocorreram em $93,3 \%$ das amostras, itens animais em $86,7 \%$ e rejeitos humanos em $16.6 \%$. Entre os vegetais, os frutos apresentaram a maior F.O. $(92,9 \%)$, seguido das folhas $(53,6 \%)$ e flores $(10,7 \%$ ). Syagrus romanzoffianum (Cham.) Glassman, 1968 e a espécie exótica Hovenia dulcis Thunberg se destacaram entre os frutos consumidos (30\% cada), e Poaceae entre as folhas consumidas. Dentre os animais, $73,3 \%$ foram invertebrados, com destaque para Orthoptera e Coleoptera (36,7\% cada), e 63,3\% foram vertebrados, destacando-se os mamíferos (33,3\%). Em relação ao método P.O. houve a supervalorização de invertebrados $(98,1 \%)$ devido ao consumo de formigas e cupins observado no estômago de um indivíduo. Em geral, $C$. thous apresentou uma dieta conforme o esperado. Seus hábitos alimentares generalistas podem influenciar positivamente sua sobrevivência em ambientes alterados. Este trabalho ainda compara diferentes métodos de análises da dieta e discute alguns comportamentos oportunistas de $C$. thous, como o consumo de espécies exóticas e o uso do ambiente de silvicultura para a caça.

PALAVRAS-CHAVE. Canídeo neotropical; carnívoros; dieta; espécie exótica; frugivoria; graxaim; silvicultura. 
Extant neotropical canids are the independent outcome of at least three lineages, and therefore do not represent a monophyletic group (XIAOMING et al. 2004). However, in contrast to species from North America and the Old World, most South American canids (except Speothos Lund, 1842) developed a hypocarnivorous habit (XIAOMING et al. 2004), in which specialized carnivory was replaced by the omnivorous habit in the Neotropics (e.g. Atelocynus Cabrera, 1940, Lycalopex Burmeister, 1854, Chrysocyon Smith, 1839, and Cerdocyon Hamilton Smith, 1839).

Cerdocyon originated in North America (XiAoming et al. 2004) and is currently considered monotypic. Its single representative is the South American Cerdocyon thous. The crab-eating fox, C. thous, is a medium-sized animal weighing between 3.7 and $11 \mathrm{~kg}$ (LANGguth 1979, Rocha et al. 2004) and presenting the most widespread geographical distribution among neotropical canids. It occurs in Colombia, Venezuela, French Guiana, Guyana, Suriname, Brazil, Bolivia, Paraguay, northern Argentina, and Uruguay (Berta 1982, Courtnay \& Maffei 2004, MAFFEI \& TABER 2003). In Brazil, this species can be found in the Cerrado, Pantanal, Caatinga, Atlantic Rainforest, grasslands, and in some localities in Amazonia (Courtnay \& Maffei 2004).

Cerdocyon thous presents, as basic social units, solitary animals, a monogamic couple or even families of up to five individuals. When foraging in pairs, it is common and occasionally cooperative (MONTGOMERY \& Lubin 1978, Courtnay \& MAFFei 2004, RochA et al. 2004). The species is considered generalist, frequently eating fruits, insects, crustaceans, eggs, small vertebrates, carcasses, and human rejects (MONTGOMERY \& Lubin 1978, BRADY 1979, Bisbal \& Ojasti 1980, Facure \& Giaretta 1996, Facure \& MonteiroFilho 1996, Delgado 2002, Juarez \& Marinho-Filho 2002, Bueno \& MotTa-Junior 2004, Jácomo et al. 2004, Rocha et al. 2004, GatTi et al. 2006, PEDó et al. 2006). Therefore, C. thous may be regarded as an opportunistic omnivorous that performs a fairly versatile role in the environments where it occurs.

This study describes, qualitatively and quantitatively, the diet of C. thous with the analysis of the stomach content of specimens which were run over in a mosaic area composed by Araucaria Pine Forest, Semidecidual Seasonal Forest, grasslands, and silviculture with native and exotic vegetation.

\section{MATERIAL AND METHODS}

\section{Study area}

The analyzed stomachs were taken from specimens from "Fazenda Monte-Alegre" (a local farm; 2412'42"S, 50³3'26”W), property of "Klabin Papel e Celulose S.A.", located in the middle stretches of Tibagi River basin, in the municipality of Telêmaco Borba, state of Paraná, Southern Brazil. This area has approximately 127.000 ha, from which 52.000 ha is of native vegetation composed by three distinct formations: Araucaria Pine Forest, Semidecidual Seasonal Forest and natural grasslands. The remaining area is formed by silvicultural exotic species such as Pinus spp., and Eucalyptus spp. and native ones such as Araucaria angustifolia (Bertol.) Kuntze (ReIs et al. 2005). The study area has average altitude of $885 \mathrm{~m}$ and the climate is mesothermic, humid subtropical, without a well-defined dry season, with the average temperature in the warmest month of $22^{\circ} \mathrm{C}$ and annual rainfall between 1300 and $1400 \mathrm{~mm}$ (NAKAJIMA et al. 1996). This region has already been a target for floristic composition and phytosociology studies in riparian areas (NAKAJIMA et al. 1996), and for mammal surveys (ReIs et al. 2002, 2005). In Fazenda Monte-Alegre C. thous is syntopic with Lycalopex vetulus (Lund, 1842), L. gymnocercus (G. Fischer, 1814), Chrysocyon brachyurus (Illiger, 1815), Procyon cancrivorus (G. Cuvier, 1798), Nasua nasua (Linnaeus, 1766), Eira Barbara (Linnaeus, 1758), Galictis cuja (Molina, 1782), Leopardus pardalis (Linnaeus, 1758), L. tigrinus (Schreber, 1775), L. wiedii (Schinz, 1821) and Puma yaguarondi (Lacépède, 1809) (ReIs et al. 2005) - carnivore species that may have similar diet habits to C. thous (Bisbal \& OJASTI 1980, Juarez \& Marinho-Filho 2002, JÁcomo et al. 2004, GatTI et al. 2006).

\section{Methods}

A total of 30 stomach content samples were taken from run over adult specimens in a stretch of the road PR-160, through "Fazenda Monte-Alegre", from January, 2001 to May, 2006. Among them there were 19 males and 11 females. The contents of each stomach were weighted and placed in $1000 \mathrm{ml}$ test tubes with water to measure their volume (see BIsbal \& OJASTI 1980). Afterwards, food items were sorted and identified to the lowest taxonomic category possible using a dissecting microscope.

The identification of plant items were made by comparison with reference material deposited in the scientific collection of the herbarium of the Universidade Federal do Paraná (UFPR) in Curitiba and also referring to NAKAJIMA et al. (1996) and LORENZI (2002). Animal items were identified using identification keys and also compared to reference collections of the following institutions in Curitiba: invertebrates at Departamento de Zoologia of UFPR and identification-key for insect orders (BuZZI 2002); vertebrates at Museu de Zoologia of Pontifícia Universidade Católica do Paraná (MZ.PUCPR), Museu de História Natural do Capão da Imbuia (MHNCI, Municipality of Curitiba, Paraná) and the Mammalian Collection of Departamento de Zoologia of the Universidade Federal do Paraná (DZUP).

Items were quantified according to their frequency of occurrence (F.O.). In this case, the presence of a certain item in a stomach was considered an occurrence, despite the number of individuals containing in the sample. For the animal items was also possible to quantify the percentage of occurrence (P.O.) by counting all occurrences of an item to estimate the minimal number of preyed individuals (EMmons 1987, KoneCNy 1989, WANG 2002).

\section{RESULTS}

The stomach contents averaged $0.11 \mathrm{~kg} \pm 0.07$ in mass and $0.121 \pm 0.10$ in volume. Females had an average of 0.094 $\mathrm{kg}$ of content per stomach, whereas males had $0.104 \mathrm{~kg}$. A total of 64 food items was found distributed among 171 occur- 
rences. Tables I and II show the items and the occurrences except for those from human rejects (one item and five occurrences). According to F.O. method, plant items corresponded to $93.3 \%$, animal items to $86.7 \%$, and human rejects (rice, bean, collared green, pork and beef) to $16.6 \%$.

Eleven species of plants were identified among four genera and 13 families. In the case of plants, fruits accounted for $92.9 \%$, leaves for $53.6 \%$ and flowers for $10.7 \%(n=28)$. Fruits of Syagrus romanzoffianum (Cham.) Glassman, 1968 and Hovenia dulcis Thunberg were the most eaten items among encountered plants (30\% each). Besides $H$. dulcis, exotic species also identified were Musa paradisiaca L., Diospyrus kaki L. f., Persea americana Mill. and Pinus spp. (10.7\%). All leaves found in the analyzed stomachs [Poaceae, Magnoliopsida and Pinus spp.] were found together with an animal prey.

Among animal items, 12 species, eight genera and 19 families were identified. Except for Sphiggurus villosus (F. Cuvier, 1823) (4 kg to $5 \mathrm{~kg}$ ), all other prey were small-sized animals (< $1 \mathrm{~kg}$ ). The F.O. was $73.3 \%$ for invertebrates and $63.3 \%$ for vertebrates. Among invertebrates, Orthoptera and Coleoptera were the most common (F.O. 36.7\% each). Evaluating vertebrates through F.O. method, mammals were found in $33.3 \%$ of the samples, reptiles and amphibians in $16.7 \%$ each, and birds in $13.3 \%$. According to P.O. method, Cricetidae represented $86.7 \%$ of consumed mammals. The percentage of occurrence (P.O.) registered $98.4 \%$ for the consumption of invertebrates and $1.6 \%$ of vertebrates $(n=2316)$. This method overestimated the relative importance of invertebrates such as Camponotus sp. (78.5\%) and the Termitidae (13.9\%), which were present in numerous individuals $(n=2144)$ exclusively in one single stomach.

\section{DISCUSSION}

The diet of $C$. thous has been quantified through different methods (e.g. direct observation, feces analysis and stomach content analysis) that report similar food items but in varying proportions (BuEno \& MotTA-Junior 2004). Nevertheless, direct observation may hinder the identification of consumed items and feces analysis may emphasize solely items of hard tissues, which may not be digested (Rосна et al. 2004, UсHOA \& MAURo-Brito 2004). The opportunistic analysis of stomach contents taken from run over animals can reveal a higher diversity in the whole set of items consumed by mesocarnivores, as it allows the analysis and the quantification of soft-tissue items. In this work soft-tissue items were registered (e.g. gastropods, oligochaetes, insect larvae, vertebrate skin, fruit pulp, leaves, flowers and rejected human food), which would be very difficult to be noticed by feces analysis. The stomach content analysis may present limitations as a quantitative method (Bisbal \& OstaJi 1980), yet it extends the knowledge about the feeding repertory of a given animal. The advantage of such material coming from run over specimens should be recommended as a supplementary tool. In addition, for abundant and frequently run over animals, this method allows a systematic survey and provides basic information while no solutions for the reduction of vehicle accidents with wild animals are determined.

In this study, C. thous presented an omnivorous diet with the consumption of plant and animal material in similar frequencies (according to F.O.), ensuring the ingestion of carbohydrates and proteins. Fruits were the plant items of major occurrence, mainly $S$. romanzoffiana e $H$. dulcis. These fruits were also very frequent in the diet of $C$. thous in a Semidecidual Seasonal Forest (Rocha et al. 2004), close to the study area of

Table I. Frequency of occurrence (F.O.) of identified Plantae taxa, discriminating parts and items found in stomachs of Cerdocyon thous.

\begin{tabular}{|c|c|c|c|}
\hline \multirow{2}{*}{ Plants } & \multirow{2}{*}{ Found item } & \multicolumn{2}{|c|}{ F.O } \\
\hline & & $\mathrm{N}$ & $\%$ \\
\hline \multicolumn{4}{|l|}{ Cecropiaceae } \\
\hline Cecropia pachystachya & Fruit & 2 & 6.7 \\
\hline \multicolumn{4}{|l|}{ Arecaceae } \\
\hline Syagrus romanzofianum & Fruit & 9 & 30.0 \\
\hline \multicolumn{4}{|l|}{ Lauraceae } \\
\hline Nectandra grandiflora & Fruit & 1 & 3.3 \\
\hline Nectandra rigida & Fruit & 1 & 3.3 \\
\hline Persea americana & Fruit & 2 & 6.7 \\
\hline Lauraceae N.I. & Fruit & 1 & 3.3 \\
\hline \multicolumn{4}{|l|}{ Rhamnaceae } \\
\hline Hovenia dulcis & Fruit & 9 & 30.0 \\
\hline \multicolumn{4}{|l|}{ Myrtaceae } \\
\hline Psidium guajava & Fruit & 1 & 3.3 \\
\hline Psidium spp. & Fruit & 3 & 10.0 \\
\hline Myrtaceae N.I. & Fruit & 1 & 3.3 \\
\hline \multicolumn{4}{|l|}{ Cucurbitaceae } \\
\hline Cucurbita sp. & Fruit & 2 & 6.7 \\
\hline \multicolumn{4}{|l|}{ Solanaceae } \\
\hline Solanum granulosoleprosum & Fruit & 1 & 3.3 \\
\hline Solanum sp. & Fruit & 1 & 3.3 \\
\hline \multicolumn{4}{|l|}{ Moraceae } \\
\hline Ficus sp. & Fruit & 1 & 3.3 \\
\hline \multicolumn{4}{|l|}{ Piperaceae } \\
\hline Piper aduncum & Fruit & 3 & 10.0 \\
\hline \multicolumn{4}{|l|}{ Ebenaceae } \\
\hline Diospyrus kaki & Fruit & 1 & 3.3 \\
\hline \multicolumn{4}{|l|}{ Musaceae } \\
\hline Musa paradisiaca & Fruit & 2 & 6.7 \\
\hline \multicolumn{4}{|l|}{ Leguminosae } \\
\hline Leguminosae N.I. & Fruits, flowers, leaves & 19 & 63.3 \\
\hline \multicolumn{4}{|l|}{ Poaceae } \\
\hline Poacae N.I. & Fruits, leaves & 15 & 50.0 \\
\hline Subtotal, Plants & & 75 & - \\
\hline
\end{tabular}


Table II. Frequency of occurrence (F.O.) and percentage of occurrence (P.O.) of identified Animalia taxa, discriminating parts and items found in stomachs of Cerdocyon thous.

\begin{tabular}{|c|c|c|c|c|c|}
\hline \multirow{2}{*}{ Animals } & \multirow{2}{*}{ Found item } & \multicolumn{2}{|c|}{ F.O. } & \multicolumn{2}{|c|}{ P.O. } \\
\hline & & $\mathrm{N}$ & $\%$ & $\mathrm{~N}$ & $\%$ \\
\hline Nematoda N.I. & entire animal & 1 & 3.3 & 1 & 0.04 \\
\hline \multicolumn{6}{|l|}{ Annelida } \\
\hline Clitellata N.I. & entire animal & 3 & 10.0 & 7 & 0.30 \\
\hline \multicolumn{6}{|l|}{ Mollusca } \\
\hline Gastropoda N.I. & entire animal & 3 & 10.0 & 8 & 0.30 \\
\hline \multicolumn{6}{|l|}{ Arthropoda } \\
\hline \multicolumn{6}{|l|}{ Odonata } \\
\hline Coenagrionidae & wings & 1 & 3.3 & 1 & 0.04 \\
\hline \multicolumn{6}{|l|}{ Orthoptera } \\
\hline Tettigonidae & Legs, wings, tagma & 1 & 3.3 & 2 & 0.09 \\
\hline Gryllidae & legs, tagma & 3 & 10.0 & 4 & 0.20 \\
\hline Gryllotalpidae & wings, legs, tagma & 1 & 3.3 & 1 & 0.04 \\
\hline Orthoptera N.I. & legs, wings & 6 & 6.7 & 8 & 0.30 \\
\hline Mantodea N.I. & entire animal, legs, wings & 3 & 10.0 & 3 & 0.09 \\
\hline Homoptera N.I. & wings & 1 & 3.3 & 1 & 0.04 \\
\hline \multicolumn{6}{|l|}{ Coleoptera } \\
\hline Cerambycidae (Ctenoscelis sp.) & entire animal, legs, antennae, eggs & 4 & 13.3 & 14 & 0.60 \\
\hline Coleoptera N.I. & larvae, elytron, abdomen, appendices & 7 & 23.3 & 10 & 0.40 \\
\hline Diptera N.I. & entire larvae & 3 & 10.0 & 30 & 1.30 \\
\hline Lepidoptera N.I. & entire larvae & 4 & 13.3 & 5 & 0.20 \\
\hline \multicolumn{6}{|l|}{ Hymenoptera } \\
\hline Formicidae (Camponotus spp.) & eggs, larvae and entire adults & 1 & 3.3 & 1822 & 78.50 \\
\hline Formicidae N.I. & entire adults & 6 & 6.7 & 33 & 1.40 \\
\hline \multicolumn{6}{|l|}{ Isoptera } \\
\hline Termitidae & entire adults & 1 & 3.3 & 322 & 13.90 \\
\hline Insecta N.I. & larvae, wings, legs, tagma & 6 & 6.7 & 7 & 0.30 \\
\hline Subtotal Invertebrates & & & 55.0 & - & 2279.00 \\
\hline Vertebrata N.I. & egg shell & 1 & 3.3 & 1 & 0.04 \\
\hline \multicolumn{6}{|l|}{ Amphibia } \\
\hline Anura N.I. & skin, bones & 1 & 3.3 & 1 & 0.04 \\
\hline \multicolumn{6}{|l|}{ Bufonidae } \\
\hline Chaunus henseli (Lutz, 1934), & entire animal & 1 & 3.3 & 1 & 0.04 \\
\hline Chaunus sp. & skin, limbs & 2 & 6.7 & 2 & 0.09 \\
\hline Leptodactylidae (Leptodactylus sp.) & skin, limbs & 1 & 3.3 & 1 & 0.04 \\
\hline \multicolumn{6}{|l|}{ Reptilia } \\
\hline Squamata N.I. & skin, limbs & 1 & 3.3 & 1 & 0.04 \\
\hline \multicolumn{6}{|l|}{ Leiosauridae } \\
\hline Anisolepis grilli Boulenger, 1891 & entire animal & 1 & 3.3 & 2 & 0.09 \\
\hline Enyalius perditus Jackson, 1978 & entire animal & 1 & 3.3 & 1 & 0.04 \\
\hline \multicolumn{6}{|l|}{ Gymnophtalmidae } \\
\hline Cercossaura schreibersii (Wiegmann, 1834) & skin, limbs, bones & 1 & 3.3 & 1 & 0.04 \\
\hline \multicolumn{6}{|l|}{ Colubridae } \\
\hline Liophis poecilogyrus (Wied-Neuwied, 1825) & entire animal & 1 & 3.3 & 1 & 0.04 \\
\hline
\end{tabular}


Table II. Continued.

\begin{tabular}{|c|c|c|c|c|c|}
\hline \multirow{2}{*}{ Animals } & \multirow{2}{*}{ Found item } & \multicolumn{2}{|c|}{ F.O. } & \multicolumn{2}{|c|}{ P.O. } \\
\hline & & $\mathrm{N}$ & $\%$ & $\mathrm{~N}$ & $\%$ \\
\hline Colubridae N.I. 1 & scales & 1 & 3.3 & 1 & 0.04 \\
\hline Colubridae N.I. 2 & scales & 1 & 3.3 & 1 & 0.04 \\
\hline Viperidae (Bothrops sp.) & scales & 1 & 3.3 & 1 & 0.04 \\
\hline \multicolumn{6}{|l|}{ Aves } \\
\hline Tinamidae: Nothura maculosa (Temminck, 1815) & feathers & 1 & 3.3 & 1 & 0.04 \\
\hline Picidae: Colaptes campestris (Vieillot, 1818) & feathers & 1 & 3.3 & 1 & 0.04 \\
\hline Rhinocryptidae (Scytalopus sp.) & feathers & 1 & 3.3 & 1 & 0.04 \\
\hline Columbidae (Leptotila sp.) & feathers, tarsi, foot, nails & 1 & 3.3 & 1 & 0.04 \\
\hline Passeriformes N.I. & feathers & 1 & 3.3 & 1 & 0.04 \\
\hline Aves N.I. & feathers & 2 & 6.7 & 2 & 0.09 \\
\hline \multicolumn{6}{|l|}{ Mammalia } \\
\hline \multicolumn{6}{|l|}{ Rodentia } \\
\hline \multicolumn{6}{|l|}{ Cricetidae } \\
\hline Brucepattersonius iheringi (Thomas, 1896) & entire animal & 1 & 3.3 & 1 & 0.04 \\
\hline Bolomys lasiurus (Lund, 1841) & head, legs, tail & 1 & 3.3 & 1 & 0.04 \\
\hline Thaptomys nigrita (Lichtenstein, 1829) & entire animal, rear part & 2 & 6.7 & 2 & 0.09 \\
\hline Akodon sp. Meyen, 1833 & entire animal & 2 & 6.7 & 2 & 0.09 \\
\hline Cricetidae N.I. & entire animal, legs, tail, vertebrae & 7 & 23.3 & 7 & 0.30 \\
\hline \multicolumn{6}{|l|}{ Cavidae } \\
\hline Cavia aperea (Erxleben, 1777) & tooth, fur & 1 & 3.3 & 1 & 0.04 \\
\hline \multicolumn{6}{|l|}{ Erethizontidae } \\
\hline Sphiggurus villous (F. Cuvier, 1823) & epiphyses, fur, tissues & 1 & 3.3 & 1 & 0.04 \\
\hline Subtotal, Vertebrates & & & 36.0 & 21.8 & 37.00 \\
\hline Total & & 91 & & 2316 & 100.00 \\
\hline
\end{tabular}

the present study, demonstrating the importance of the native palm tree and the opportunism for exotic species in its diet. Although fruits were most frequently found, leaves were representative, as well. Magnoliopsida and Pinus leaves might have been accidentally ingested together with their prey (all occurred together with animal prey). In Pinus plantation areas there is an accentuated deposition of leaves by the planted trees. Cerdocyon thous is often observed foraging in such areas, which reinforces the hypothesis of accidental ingestion. UсноA \& Moura-BritTo (2004) also found C. thous visiting monocultures of Pinus spp. in Paraná's Cerrado. In this kind of monoculture some rodents, such as Olygoryzomys nigripes (Olfers, 1818), Akodon montensis Thomas, 1913, Delomys dorsalis (Hensel, 1872) and Euryzygomatomys spinosus (G. Fischer, 1814) (Gonçalvez et al. 2007) are present and may attract C. thous. The consumption of Poaceae leaves, on the other hand, may have been intentional, for its frequency was higher than other kinds of leaf. This is seemingly common among carnivores and may be intentional in order to augment digestion efficiency (DieTz 1984, Bueno \& MotTa-Junior 2004, Rocha et al. 2004).
Cerdocyon thous ate mainly small animal prey, except for S. villosus. Apparently, C. thous has limitations to capture animals of larger size (BISBAL \& OJASTI 1980), which do not occur with similar sized felids [e.g. Leopardus pardalis (Linnaeus, 1758) (Abreu et al. 2008)]. This restriction may be a consequence of two main factors: 1) solitary life style or in couples. The absence of cooperative hunt does not allow the capture of prey larger than itself, as it is observed in social canids that hunt in groups [e.g. Speothos venaticus (Lund, 1842), Canis lupus Linnaeus, 1758, C. latrans Say, 1823, Cuon alpinus (Pallas, 1811) and Lycaon pictus Temminck, 1820 (WAllace et al. 2002, NowAK 1999)]. 2) The less specialized morphology of canids when compared to felids. The relative lack of specializations for predation can enhance the generalist feeding habit for small animals and plants.

Small vertebrates and invertebrates were found in similar frequencies (according to F.O.). Among invertebrates, arthropods were the most frequent, especially orthopterans and coleopterans, as already demonstrated by other authors (МоттAJunior et al. 1994, Facure \& Monteiro-Filho 1996, Juarez \& Marinho-Filho 2002, Rocha et al. 2004, GatTi et al. 2006). Mam- 
mals were more frequent among vertebrates, with Cricetidae rodents being the most common. These rodents are usually the most abundant terrestrial vertebrates in neotropical forests (Solari \& Rodrigues 1997). This and other studies showed that rodents are the mammals most frequently consumed by $C$. thous throughout its geographical distribution, exceeding the consumption of other vertebrate classes (MotTA-Junior et al. 1994, Facure \& Monteiro-Filho 1996, Delgado 2002, Juarez et al. 2002, Jácomo et al. 2004, Rocha et al. 2004, Pedó et al. 2006). An exception for this pattern was detected by GATTI et al. (2006) in a "restinga" area where reptiles were the most frequent vertebrates in its diet.

In the present study, reptiles and amphibians were the second most frequently consumed vertebrates, with special emphasis to poisonous animals, such as those belonging to Bothrops Wagler, 1824 and Chaunus Wagler, 1828. Rocha et al. (2004) suggested that $C$. thous may assimilate dead specimens or has any particular behavioral strategy for catching poisonous animals. The toxic prey found in the analyzed stomachs were well preserved, especially Chaunus, thus, suggesting they were captured alive. Experimental observations with captive and wild specimens may demonstrate such behavior and indicate whether $C$. thous is resistant to those toxins.

The birds were the least frequently consumed vertebrates and the identified items suggest that all species inhabit the lowest layer and ground of the environment, facilitating predation by C. thous. Nothura maculosa (Temminck, 1815), Colaptes campestris (Vieillot, 1818), Leptotila sp. Swainson, 1837 and Scytalopus sp. Gould, 1837 are birds that use the ground as their main foraging site, making them vulnerable to terrestrial carnivores. In conclusion, the consumption of vertebrates by $C$. thous appears to be defined primarily as a consequence of small size, abundance and terrestrial habit of its prey (BRADY 1979).

The P.O. method overestimated the consumption of invertebrates, because one of the sampled stomachs contained only ants and Termitidae associated in large numbers. These items are not often found in the crab-eating fox diet but are commonly found on the hoary fox diet, L. vetulus (CourTenay et al. 2006). Termitidae predation by Camponotus Mayr, 1861 is a well known event (Hölldobler \& Wilston 1990), then, the most parsimonious possibility is that, in that occasion, the given $C$. thous specimen was benefited by a possible interaction between Camponotus and the Termitidae (Marcio R. Pie, Departamento de Zoologia, Universidade Federal do Paraná, pers. comm.).

This study evidenced one more time the opportunistic behavior of $C$. thous with the consumption of exotic species, human rejects and also the use of silviculture areas for foraging (inferred by the presence of Pinus sp. leaves associated to the prey). Hence, despite the influence of exotic plantations inside the surveyed mosaic, the diet of $C$. thous is in agreement to the already known for the species (MONTGOMERY \& LubIN 1978, Brady 1979, Bisbal \& OJasti 1980, Facure \& Giaretta 1996, Facure \& Monteiro-Filho 1996, Delgado 2002, Juarez \& Marinho-Filho
2002, Bueno \& Motta-Junior 2004, Jácomo et al. 2004, Rocha et al. 2004, GatTi et al. 2006, Pedó et al. 2006), strongly suggesting that its generalist habits enables its survival in environments modified by humans.

\section{ACKNOWLEDGMENTS}

We thank Klabin S.A., CNPq for scholarships to L.M. Aguiar, R.F. Moro-Rios and for research grants to F.C. Passos (Process 3306194/2006-6), and CAPES for scholarship to J.E. Silva-Pereira. We also thank Julio C.M. Leite for the identification of amphibians and reptiles, Raphael E.F. Santos for the identification of birds and Estefano F. Jablonski for help on the identification of mammals. We are also indebted to Jordana Gianezini and to Kaue C. Abreu. Carolina C. Cheida and two anonymous reviewers provided helpful suggestions. This is the contribution number 1734 of the Departamento de Zoologia, Universidade Federal do Paraná.

\section{LITERATURE CITED}

Abreu, K.C.; R.F. Moro-Rios; J.E. Silva-Pereira; J.M.D. Miranda; S.F. Jablonski \& F.C. Passos. 2008. Feeding habits of ocelot (Leopardus pardalis) in Southern Brazil. Mammalian Biology 73: 407-411.

BerTA, A. 1982. Cerdocyon thous. Mammalian species 186: 1-4. Bisbal, F. \& J. OJasti. 1980. Nicho trofico del zorro Cerdocyon thous (Mammalia, Carnivora). Acta Biologica Venezuelana 10 (4): 469-496.

BRADY, C.A. 1979. Observations on the behavior and ecology of the crab-eating fox (Cerdocyon thous), p. 161-167. In: J.F. Eisenberg (Ed). Vertebrate ecology in the Northern Neotropics. Washington, Smithsonian Institution Press, 271p.

Bueno, A.A. \& J.C. Motta-Junior. 2004. Food habits of two syntopic canids, the maned wolf (Chrysocyon brachyurus) and the crab-eating fox (Cerdocyon thous), in southeastern Brazil. Revista Chilena de Historia Natural 77: 5-14.

BuZZI, Z.J. 2002. Entomologia didática. Curitiba, EDUFPR, 347p. Courtenay, O. \& L. Maffer. 2004. Crab eating fox, Cerdocyon thous (Linnaeus, 1766), p. 30-38. In: C. Sillero-Zubiri; M. HoffmanN \& D.W. Macdonald (Eds). Canids: foxes, wolves, jackals and dogs. Status survey and conservation action plan. Cambridge, IUCN/SSC Canid Specialist Group, X+430p.

Courtenay, O.; D.W. Macdonald; S. Gillingham; G. Almeida \& R. DiAs. 2006. First observations on South America's largely insectivorous canid: the hoary fox (Pseudalopex vetulus). Journal of Zoology 268 (1): 45-54.

Delgado, V.C.A. 2002. Food habits and habitat of the crab eating fox Cerdocyon thous in the higlands of eastern Antioquia, Cordilheira Central, Colombia. Mammalia 66 (4): 599-602.

DieTz, J.M. 1984. Ecology and social organization of the maned wolf (Chrysocyon brachyurus). Smithsonian Contributions to Zoology 392 (1): 1-51. 
Emmons L.H. 1987. Comparative feeding ecology of felids in a neotropical rain forest. Behavioral Ecology and Sociobiology 20 (1): 271-283.

Facure, K.G. \& E.L.A. Monteiro-Filho. 1996. Feeding habits of the crab-eating fox Cerdocyon thous (Carnivora, Canidae) in a suburban area of southeastern Brazil. Mammalia 60 (1): 147-149.

Facure, K.G. \& A.A. Giaretta. 1996. Food habits of carnivore in a costal Atlantic forest of southeastern Brazil. Mammalia 60 (3): 499-502.

Gatti, A.; R. Bianchi; C.R.X. Rosa \& S.L. Mendes. 2006. Diet of two sympatric carnivores, Cerdocyon thous and Procyon cancrivorus, in a restinga area of Espirito Santo State, Brazil. Journal of Tropical Ecology 22 (1): 227-230.

Gonçalvez, G.L.; G.V. Faria-Correa; A.S. Cunha \& T.R.O. Freitas. 2007. Bark consumption by the sipy rat Euryzygomatomys spinosus (G. Fischer) (Echymidae) on a Pinus taeda Linnaeus (Pimaceae) plantation in South Brazil. Revista Brasileira de Zoologia 24 (1): 260-263.

Hölldobler, B. \& E.O. Wilson. 1990. The ants. Massachusetts, Harvard University Press, 732p.

Jácomo, A.T.A.; L. Silveira \& J.A.F. Diniz-Filho. 2004. Niche separation between the maned wolf (Chrysocyon brachyurus), the crab-eating fox (Dusicyon thous) and the hoary fox (Dusicyon vetulus) in central Brazil. Journal of Zoology 262 (1): 99-106.

Juarez, K.M. \& J. Marinho-Filho. 2002. Diet, habitat use, and home ranges of sympatric canids in central Brazil. Journal of Mammalogy 83 (4): 925-933.

Konecny, M.J. 1989. Movement patterns and food habits of four simpatric carnivore species in Belize, Central América, p. 243-264. In: K.H. RedFord \& J.F. Eisenberg (Eds). Advance in Neotropical Mammalogy. Gainsville, Sandhill Crane Press, $614 \mathrm{p}$.

LANGGUTH, A. 1979. Ecology and evolution in the south american canids, p. 193-206. In: M.W. Fox (Ed). The wild canids. New York, Van Nostrand Reinhold, 508p.

LoRENZI, H. 2002. Árvores Brasileiras: manual de identificação e cultivo de plantas arbóreas nativas do Brasil. Nova Odessa, Instituto Plantarum, 726p.

Maffei, L. \& B.A. Taber. 2003. Área de accón, actividad y uso de hábitat del zorro patas negras, Cerdocyon thous, en un Bosque seco. Mastozoologia Neotropical 10: 154-160.

MotTa-Junior, J.C.; J.A. Lombardi \& S.A. Talamoni. 1994. Notes on crab-eating fox (Dusicyon thous): Seed dispersal and food habits in southeastern Brazil. Mammalia 58 (1): 156-159.

Montgomery, G.G. \& Y.D. Lubin. 1978. Social structure and food habits of crab-eating fox (Cerdocyon thous) in venezuelan llanos. Acta Cientifica Venezolana 29: 382-383.

Nakajima, J.N.; L.H. Soares-Silva; M.E. Medri; R. Goldenderg \& G.T. Correa. 1996. Composição florística e fitossociologia do componente arbóreo das florestas ripárias da Bacia do Rio Tibagi: 5. Fazenda Monte-Alegre, Município de Telêmaco Borba, Paraná. Arquivos Brasileiros de Biologia e Tecnologia 39 (4): 933-948.

NowAK, R.M. 1999. Walker's mammals of the world. Baltimore and London, The Johns Hopkins University Press, 836p.

Pedó, E.; A.C. Tomazzoni; S.M. Hartz \& A.U. Christoff. 2006. Diet of Crab Eating Fox, Cerdocyon thous (Linnaeus) (Carnivora, Canidae) in a suburban area of Southern Brazil. Revista Brasileira de Zoologia 23 (3): 637-641.

Reis, N.R.; A.L. Peracchi \& I.P. Lima. 2002. Morcegos da bacia do rio Tibagi, p. 251-270. In: M.E. Medri; E. Bianchini; O.A. Shibatta; J.A. Pimenta (Eds). A Bacia do Rio Tibagi. Londrina, Eduel, 595p.

Reis, N.R.; A.L. Peracchi; J.H.F. Marino \& V.J. Rocha. 2005. Mamíferos da Fazenda Monte-Alegre, Paraná. Londrina, Eduel, 202p.

Rocha, V.J.; N.R. Reis \& M.L. Sekiama. 2004. Dieta e dispersão de sementes por Cerdocyon thous (Linnaeus) (Carnivora, Canidae) em um fragmento florestal no Paraná, Brasil. Revista Brasileira de Zoologia 21 (4): 871-876.

SOlARI, S. \& J.J. RODRIGUes. 1997. Assessment and monitoring mammals: small and non-volant mammals, p. 281-290. In: F. Dallmeier \& A. Alonso (Eds). Biodiversity assessment and long-term monitoring of the Lower Urubamba Region, Peru. Washington, Smithsonian Institution Monitoring Assessment of Biodiversity Program, 293p.

UchoA, T. \& M. Moura-BritTo. 2004. Hábito alimentar e uso do habitat por canídeos no Parque Estadual do Cerrado: avaliação da situação atual da família Canidae no limite sul do bioma Cerrado no Brasil. Cadernos da Biodiversidade 4 (2): 59-65.

Xiaoming, W.; R.H. Tedford; B. Van Valkenburgh \& R.K. Wayne. 2004. Phylogeny, Classification, and Evolutionary Ecology of the Canidae, p. 6-20. In: C. Sillero-Zubiri; M. Hoffmann \& D.W. MACDONALD (Eds). Canids: foxes, wolves, jackals and dogs. Status survey and conservation action plan. Cambridge, IUCN/SSC Canid Specialist Group, X+430p.

Wallace, R.B.; R.L.E. Panter; A. Saldania. 2002. An observation of Bush Dogs (Speothos venaticus) hunting behavior. Mammalia 66 (2): 309-311.

WANG, E. 2002. Diets of ocelots (Leopardus pardalis), margays (L. wiedii) and oncillas (L. tigrinus) in the Atlantic rainforest Southeast Brazil. Studies in Neotropical Fauna and Enviromnents 37 (3): 207-212.

Submitted: 23.I.2008; Accepted: 31.X.2008.

Editorial responsibility: Luciano Martins Verdade 